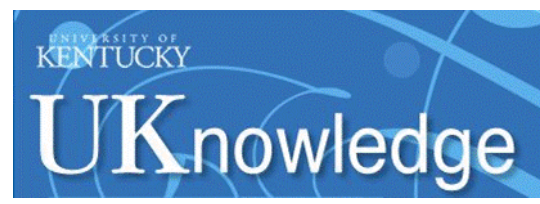

University of Kentucky

UKnowledge

7-2005

\title{
A Model Program for Youth Suicide Prevention
}

Hatim A. Omar

University of Kentucky, hatim.omar@uky.edu

Follow this and additional works at: https://uknowledge.uky.edu/pediatrics_facpub

Part of the Mental and Social Health Commons, and the Pediatrics Commons

Right click to open a feedback form in a new tab to let us know how this document benefits you.

\section{Repository Citation}

Omar, Hatim A., "A Model Program for Youth Suicide Prevention" (2005). Pediatrics Faculty Publications. 70.

https://uknowledge.uky.edu/pediatrics_facpub/70

This Article is brought to you for free and open access by the Pediatrics at UKnowledge. It has been accepted for inclusion in Pediatrics Faculty Publications by an authorized administrator of UKnowledge. For more information, please contact UKnowledge@lsv.uky.edu. 


\section{A Model Program for Youth Suicide Prevention}

\section{Digital Object Identifier (DOI)}

http://dx.doi.org/10.1515/IJAMH.2005.17.3.267

\section{Notes/Citation Information}

Published in International Journal of Adolescent Medicine and Health, v. 17, no. 3, p. 267-274.

(c) Freund Publishing House Ltd.

The copyright holder has granted permission for posting the article here.

Reprinted as a book chapter in Rural Child Health: International Aspects, Erica Bell \& Joav Merrick (Eds.), p. 167-170.

Reprinted as a book chapter in Adolescent Behavior Research: International Perspectives. Joav Merrick, \& Hatim A. Omar, (Eds.). p. 75-78. 


\section{A model program for youth suicide prevention}

\section{Hatim A Omar, MD}

\section{Section of Adolescent Medicine, University of Kentucky, Lexington, KY, USA}

Abstract: Youth suicide continues to be one of the leading causes of death in the United States. Nation wide it is the third leading cause of death in the 10-24 year old age group. The rate of suicide varies somewhat from state to state. In the state of Kentucky, youth suicide is the second leading cause of death. This article describes a grass root, community-based program for youth suicide prevention and its impact on the community. The Stop Youth Suicide Campaign was launched in October 2000 and included more than 30 local agencies. This program worked through public education, education of medical care providers, schoolteachers, school counselors, youth service center personnel and many other entities that deal with adolescents. This program utilized face-to-face encounters, website, video and other forms of media education. Over a four-year period, the program has provided several conferences and many lectures and workshops to the community. The program has responded to many e-mails and phone calls from teens and/or their parents asking for help. During these years, many of these children that were seeking help ended up receiving appropriate help that contributed to changing their lives and helping them stay alive and also utilizing them to help others in that period. Simple grass roots programs are able to help and are needed in the community to combat this epidemic that is causing significant mortality and morbidity.

Keywords: Adolescents, youth suicide, depression, adolescent mortality, suicide prevention, USA

Correspondence: Hatim Omar, MD, Professor of Pediatrics and ObstetricslGynecology, Director, Adolescent Medicine, University of Kentucky, 740 South Limestone Street, Kentucky Clinic, J422, Lexington, KY 40536, USA. Tel: 859-323-5643; Fax: 859-257-7706; Email. Haomar2@uky.edu

Received: November 01, 2004. Revised: January 10, 2005. Accepted: January 11, 2005.

\section{INTRODUCTION}

Youth suicide has been a major contributing factor to mortality and morbidity over the last thirty to forty years. It has consistently been one of the leading causes of death among teenagers 10-24 years of age and has been the third leading cause of death over all in the United States among this age group. According to the Center for Disease Control, 2003 Risk Youth Behavior Survey, an average of 8.5 percent of youth have actually attempted suicide(1). A 21 year old longitudinal study by Ferguson reports (2) suicide ideation in $28.8 \%$ of youth and suicide attempts in $7.5 \%$ by age 21 years. Autopsies of youth successfully completing suicide have identified numerous factors more significantly associated with suicide completers than with controls. These factors include non-intact family of origin, less frequent and satisfying communication with parents, history of mood disorder in mother, history of legal problems in father, family history of suicidal behavior, recent discipline (especially school suspension and juvenile court appearance), recent break up with boyfriend or girlfriend, recent separation of parents, lack of employment or school attendance, or grade failure (3) and the presence of DSM-III diagnosis (4) especially mood disorder, anxiety disorder 
and disruptive disorders. According to prior studies, predictors of suicide attempts include parental depression, poor family functioning (5), large number of parental changes, poor attachment to parents, exposed to sexual abuse (6), depression, hopelessness (7), anxiety disorder and substance abuse (8). Primary reasons reported for suicide attempts when given a list to choose from include: to die, relief from state of mind, escape from a situation and to make others understand how desperate one feels (9). We have previously found that one of the most quoted reasons for attempted suicide in Central Kentucky as reported by teenagers who were admitted to emergency rooms for attempted suicide was conflict with parent followed by conflict with significant other (10).

\section{METHODS}

\section{Program description}

The program was named "Stop Youth Suicide Campaign" and started officially in October 2000 . Campaign was started by a coalition including thirty agencies in the Central Kentucky area such as the Adolescent Medicine program at the University of Kentucky (leader of the coalition), the Coroner's Office, the heath department, several local media outlets, participants from the school system, parent groups and many others. The goal of the program was: 1) To improve community awareness of the problem of youth suicide. 2) To assess the need in the community and basic knowledge on youth suicide. 3) To start a public education campaign targeting parents, teachers and everyone who has anything to do with teens. 4) To provide for improved education of medical care providers that deal with adolescents and to improve their knowledge and comfort level in screening and assessing for depression and suicide. 5) To provide around the clock, available help to any teenagers in the area who were suicidal or need help in that regard.

To accomplish these goals, the campaign started with a media press conference and an announcement by the mayor's office in Lexington, $\mathrm{KY}$ to inform the people of the area about the program. This was followed by several days of media information on the government television channel in the area. The campaign then started a website (www.stopyouthsuicide.com) that is available to anyone to access information on youth suicide and to be able to contact the campaign in case help is needed. The campaign then produced a local video showing teenagers, who had attempted suicide and survived, parents of youth who committed suicide and friends or peers of youth who have completed suicide as well as experts discussing ways and means on how to understand youth suicide and work on youth suicide prevention. The next step was to offer education to providers, which was done through providing numerous lectures and workshops. From October 2000 to December 2004, a total of 60 lectures and workshops and three full day conferences devoted to youth suicide prevention training to medical care providers of all levels. The campaign has also participated in working with the state government and local agencies to build and establish a State-wide youth suicide prevention program. In addition, the Stop Youth Suicide Campaign had participated in church and school activities in multiple visits to all area middle and high schools as well as religious activities to educate parents on the problem of youth suicide.

\section{RESULTS}

Over the last four years, between October 2000 and 2004 the Stop Youth Suicide Campaign has received a total of 861 emails and 976 phone calls from teenagers who were contemplating suicide and asking 
for help and 26 e-mails and 112 phone calls from parents of teens at risk. These patients were appropriately treated in the area and referred to appropriate people if they were out of the area. A total of thirteen teenagers who were acutely suicidal with plan and readiness to complete it at the time of contacting the program were helped to change their minds and to continue to be alive as of this date. Several of the teens helped by the program have joined the campaign to help other teens. Public awareness in the area regarding youth suicide has improved based on surveys done before the launching of the program and three years after (Omar H. Unpublished observations 2003). Also, the Stop Youth Suicide Campaign played a significant role in working with the state on establishing a state suicide program that is now ongoing.

\section{DISCUSSION}

The leading causes of death in the adolescent age group in the United States are accidents, homicide and suicide, all preventable (1). Suicide is the $2^{\text {nd }}$ leading cause of death among adolescents in Kentucky and at the time of launching the Stop Youth Suicide Campaign, no other program existed in the state. Government agencies chronically lack funding for such preventive programs. Adolescent medicine specialists are the best trained professionals in understanding adolescent development as well as risk and protective factors for morbidity and mortality in this group. It should be our role (adolescent medicine specialists) to educate other health care providers and the public and to take a leading role in serving the community and advocating for the well being of adolescents. Utilizing community resources can help alleviate lack of government funding for such preventive program. The Stop Youth Suicide Campaign was able to utilize volunteers and various community resources to develop a long lasting, helpful program for prevention of youth suicide that have contributed to helping many teens at risk of suicide and improving there lives. This article is a simple descriptive presentation, so it does not provide scientific study results. It does however show that committed medical providers can help utilize community resources and with hard work, caring and dedication, can develop useful programs to provide help to distressed teens and their parents.

\section{REFERENCES}

1. Centers for Disease Control and Prevention. Surveillance Summaries, May 21, 2004. MMWR 2004;53:25-7.

2. Fergusson DM, Woodward LJ, Horwood LJ. Risk factors and life processes associated with the onset of suicidal behavior during adolescence and early adulthood. Psychol Med 2000;30:23-39.

3. Gould MS, Fisher P, Parides M, Flory $M$, Shaffer D. Psychological risk factors of child and adolescent completed suicide. Arch General Psychiatr 1996;53:1155-62.

4. Shaffer D, Gould MS, Fisher P, Trautman P, Moreau D, Kleinman M, Flory M. Psychiatric diagnosis in child and adolescent suicide. Arch General Psychiatr 1996;53: 339-48.

5. Garber J, Little S, Hilsman Ruth, Weaver KR. Family predictors of suicidal symptoms in young adolescents. J Adolesc 1998;21:44557.

6. Overholser JC, Freiheit SR, DiFilippo JM (1987), Emotional distress and substance abuse as risk factors for suicide. Can J Psychiatr 1997;42:4028.

7. Gould MS, King R, Greenwald S, Fisher P, Schwab-Stone M, Kramer R, Flisher AJ, Goodman S, Canino G, 
Shaffer D. Psychopathology associated with suicidal ideation and attempts among children and adolescents. J Am Acad Child Adolesc Psychiatr 1998;37:915-23.

8. Boergers J, Spirito A, Donaldson D. Reasons for adolescent suicide attempts: associations with psychological functioning. J Am Acad Child Adolesc Psychiatr 1998;37:1287-93.

9. Negron R, Placentini J, Graae F,
Davies M, Shaffer D. Microanalysis of adolescent suicide attempters and ideators during the acute suicidal episode. J Am Acad Child Adolesc Psychiatr 1997;36:1512-9.

10. Omar H, Hagedorn J. Retrospective Analysis of Youth Evaluated for Suicide Attempt or Suicidal Ideation in an Emergency Room Setting Int $J$ Adolesc Med Health 2001;14(1):5560 .

\section{BITS 'N PIECES}

Delayed Prescription May Reduce the Use of Antibiotics for Acute Otitis Media A Prospective Observational Study in Primary Care

Objectives To evaluate the applicability and the effectiveness of practice guidelines based on a wait-and-see strategy for children with acute otitis media (AOM). Population Children from 1 to 14 years old having AOM who were referred to primary care pediatric practices. Study Design Prospective observational study. Main Outcome Measure Proportion of children having a diagnosis of AOM and eligible for symptomatic treatment who, at 72 hours from enrollment, recovered from their symptoms (fever and earache) without receiving antibiotic treatment. Results One hundred sixty-nine pediatricians participated in the study and enrolled 1672 children. One thousand two hundred seventy-seven children were included in the analysis. One hundred seventy-eight children received antibiotic treatment at first contact according to the practice guidelines criteria (presence of otorrhea or recurrent $A O M)$. Of the 1099 children who were eligible for symptomatic treatment only, $743(67.6 \%)$ recovered without antibiotic treatment at 3 days and $716(65.1 \%)$ at 30 days. No complications were observed. Coexistence of a high fever (temperature $38.4^{\circ} \mathrm{C}$ ) and red and bulging tympanic membrane as well as male sex were significantly associated with antibiotic use. Conclusions Practice guidelines based on a wait-and-see strategy for children with AOM are applicable and effective in primary care. This strategy was able to avoid the administration of antibiotic treatment in 2 of 3 children.

Marchetti F, Ronfani L, Nibali SC, Tamburlini G. Arch Pediatr Adolesc Med. 2005;159:679-84. 